\title{
Development Strategies for Woven SMEs in Medan
}

\author{
Inggrita Gusti Sari Nasution \\ Department of Development Economic \\ University of Sumatera Utara \\ Medan, Indonesia \\ inggritagusti@gmail.com
}

\author{
Frida Ramadini \\ Department of Management \\ University of Sumatera Utara \\ Medan, Indonesia \\ (dhini92@gmail.com)
}

\begin{abstract}
This research aims to implement development strategies for woven SMEs in Medan. Data used was primary data from depth interview with the woven SMEs in Medan. Sampling technique used was a nonprobability sampling. SWOT analysis by comparing internal and external factors was used for data analysis. The research shows woven SMEs are in the first quadrant for growth strategy. Therefore, the implementation of development strategies in woven SMEs in Medan are to increase woven quality by utilising the availability of weavers and develop creative entrepreneurship.
\end{abstract}

Keywords - Development strategies; Implementation; woven SMEs

\section{INTRODUCTION}

Small and medium enterprises (SMEs) are the backbone of Indonesian economy and therefore it is an important part in it. As one of the pillars, SMEs are a priority sector needed to be improved to develop the economy. SMEs improvement able to give contribution and become the support to and for economic development.

To compete, SMEs need sustainable competitive advantage strategy. Competitiveness has the influence to significantly increase productivity and it enlarges market access which results in the increase of turnover and profit.

One of the developing SMEs in Medan is in woven product which is very prospective as it can raise local culture. Woven is Indonesia's cultural wealth and is a part of a national culture that has to be preserved. Medan's woven with a variety of ethnicity motives is unique and has the potential to be developed.

Problems existing in woven SMEs are the human resources (weavers), government support and the consumers. The existence of galleries has supported a number of woven SMEs and improved the business [1]. With those problems, woven SMEs have always tried to increase competitiveness. In order to grow and develop as well as arising their existence and ensuring sustainability to improve local economy, sustainable competitive advantage strategy needs to be implemented.

There are still ways and efforts can be done for the development of SMEs. These are expected to increase the creativity, overtness and optimism in running and developing the business. At the same time they prevent the businessmen to be limited to the mindset of custom management in managing SMEs.

\section{A. Problems}

The outline of problem in this research is the strategies needed to be implemented for the improvement of woven SMEs in Medan.

\section{B. Research Purposes}

The purpose of this result is to analyse the strategies which can be implemented for the improvement of woven SMEs in Medan.

\section{THEORY AND HYPOTHESIS}

\section{A. Small and Medium Enterprises (SMEs)}

According to Undang - Undang or the laws of the Republic of Indonesia Number 20 Year 2008 about micro ventures, small and medium businesses defines small businesses as independent and economically productive, run by an individual or a business entity which is not a subsidiary or branch of the companies owned and managed by medium or big businesses or even as a part of those either directly or indirectly. These criterias are how small businesses are categorized according to the valid laws [2].

Despite the number of definitions for small businesses, they have almost the same characteristics. First, there is no clear job description between administration and operation. Most small industries 
are managed by individuals who own the businesses and manage the company, also recruit workforce from the family or close relatives. Second, small industries have minimum access to formal credit institutions therefore overheads come from personal equity or other sources like families, relatives, intermediary traders or even from creditors. Third, having no legal entity status is the indicator of small businesses [3].

The success of SMEs has the direct impact to the development of national economy both in developed and developing countries [4]. SMEs are able to create employment with minimum cost. Furthermore they are the pioneers in innovating and have high flexibility which make them possible to fulfill customers' needs [5][6].

\section{B. Competitiveness}

Competitiveness is the ability to maintain market share. It can significantly influence a company's productivity and enlarge market access. As a result, there will be an increase in turnover and profit margins. Several indicators that can be used to measure competitiveness are increase in output value or volume, product innovations, market share, turnover, product quality, profit margins, education background of workers and employers, the number of standardizations and certifications, patents bought, the technology used, marketing, production, productivity or efficiency, value of machines and production tools or assets value, total promotion cost and networks or affiliations [7].

SMEs with excellent competitiveness have these characteristics: (a) having good human resources, (b) optimum technology utilization, (c) are efficient and able to increase productivity, (d) able to increase product quality, (e) have a large promotion access, (f) have a structured management, (g) have sufficient capital resource, and (i) have entrepreneurship skill [8].

\section{RESEARCH METHODOLOGY}

Research was conducted to woven SMEs in Medan. Sampling technique used was non probability sampling with saturated sample or census due to the small population size. According to Sugiyono (2013) saturated sample is a sampling technique where all populations members are the samples. This is often be the case with small population size which is less than 30 people. Method used for SMEs development strategies was SWOT analysis. It is used to identify several factors systematically to formulate development strategies. This analysis is based on the logic that can maximize strengths and opportunities but at the same time able to minimize weaknesses and threats. SWOT analysis compare external factors, opportunity and threat with internal factors, strength and weakness.

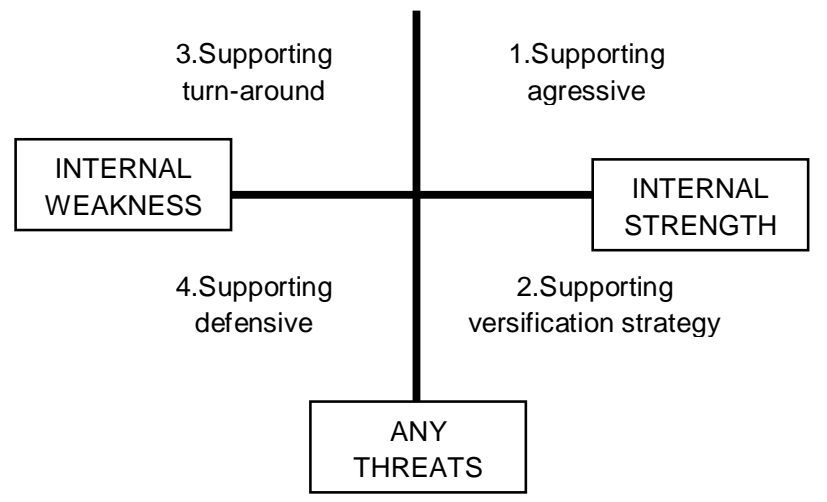

Fig 1. SWOT Analysis

Quadrant 1: is a very benefitting situation because SMEs have the strengths and opportunities therefore can make use of the existing opportunities. And the strategy needs to be implemented is to support aggressive growth plan (growth oriented strategy).

Quadrant 2: Despite the threats, SMEs still have internal strength. Strategy to implement is by utilizing the long term opportunities through diversification strategy in products or markets.

Quadrant 3: SMEs are facing big market opportunities but at the same time they are also facing internal threats. SMEs focus is to minimize internal problems to seize better market opportunities.

Quadrant 4: is the drawbacks for SMEs as they are facing internal threats and weaknesses.

\section{RESULT AND DISCUSSION}

Below is the strength and weakness also opportunity and threat factors for woven SMEs in Medan presented in tables. 
TABLE 1. Strength and Weakness Factors for Woven SMEs

\begin{tabular}{|c|c|c|c|c|c|c|}
\hline $\begin{array}{c}\text { INTERNAL } \\
\text { STRATEGY } \\
\text { FACTORS }\end{array}$ & SP & $\mathrm{K}$ & SPxK & WEIGHT & RATING & SCORE \\
\hline Strength (S) & & & & & & \\
\hline $\begin{array}{l}\text { 1. Weavers } \\
\text { availability }\end{array}$ & 3 & 8 & 24 & 0,15 & 3 & 0,45 \\
\hline $\begin{array}{l}\text { 2. Entrepreneurial } \\
\text { totality }\end{array}$ & 4 & 8 & 32 & 0,2 & 4 & 0,8 \\
\hline $\begin{array}{l}\text { 3. Product } \\
\text { diversification }\end{array}$ & 2 & 8 & 16 & 0,1 & 3 & 0,3 \\
\hline $\begin{array}{l}\text { 4. Easy access to } \\
\text { raw materials }\end{array}$ & 1 & 8 & 8 & 0,05 & 3 & 0,15 \\
\hline SUB TOTAL & & & & & & 1,7 \\
\hline $\begin{array}{l}\text { Weakness (W) } \\
\text { 1. Low quality } \\
\text { weavers }\end{array}$ & 4 & 8 & 32 & 0,2 & 2 & 0,4 \\
\hline 2. High products cost & 1 & 8 & 8 & 0,05 & 1 & 0,05 \\
\hline marketers & 3 & 8 & 24 & 0,15 & 2 & 0,3 \\
\hline $\begin{array}{l}\text { 4. Inefficient use of } \\
\text { social media }\end{array}$ & 2 & 8 & & & 1 & 0,1 \\
\hline SUB TOTAL & & & & & & 0,85 \\
\hline TOTAL & & & 160 & 1,00 & & 2,55 \\
\hline
\end{tabular}

TABLE 2. Opportunity and Threat Factors for Woven SMEs

\begin{tabular}{|l|l|l|l|l|l|l|}
\hline \begin{tabular}{|} 
EXTERNAL \\
STRATEGY FACTORS
\end{tabular} & SP & $\mathbf{K}$ & SPxK & WEIGHT & RATING & SCORE \\
\hline $\begin{array}{l}\text { Opportunity (O) } \\
\text { 1. Cultural legacy } \\
\text { 2. Regional tourist } \\
\text { attraction }\end{array}$ & 4 & 8 & 32 & 0,2 & 4 & 0,8 \\
$\begin{array}{l}\text { 3. Affiliation with Bank } \\
\text { Indonesia }\end{array}$ & 2 & 8 & 8 & 0,05 & 2 & 0,10 \\
4. Galleries ownership & 3 & 8 & 24 & 0,15 & 4 & 0,4 \\
\hline SUB TOTAL & & & & & & 0,6 \\
\hline $\begin{array}{l}\text { Threat (T) } \\
\text { 1. Insufficient }\end{array}$ & 4 & 8 & 32 & 0,2 & 2 & 1,9 \\
$\begin{array}{l}\text { government support } \\
\text { 2. Complicated } \\
\text { bureaucracy }\end{array}$ & 2 & 8 & 16 & 0,1 & 1 & 0,4 \\
$\begin{array}{l}\text { 3. Consumers mindset } \\
\text { 4. Community absence }\end{array}$ & 1 & 8 & 8 & 0,05 & 3 & 0,1 \\
\hline SUB TOTAL & 8 & 24 & 0,15 & 3 & 0,15 \\
\hline TOTAL & & & 160 & 1,00 & & 1,1 \\
\hline
\end{tabular}

From Table 1, the score for strength factor is 1.7 and weakness factor is 0.85 . Strength's score is bigger than weakness' with a difference of $(+) 0.85$. While in Table 2, the score for opportunity factor is 1.9 and threat factor is 1.1. Opportunity's score is bigger than threat's with a difference of $(+) 0.8$. Then those differences were drawn in SWOT diagram where strength and opportunity factors are a (+) value and weakness and threat factors are (-) value. SWOT diagram is presented below.

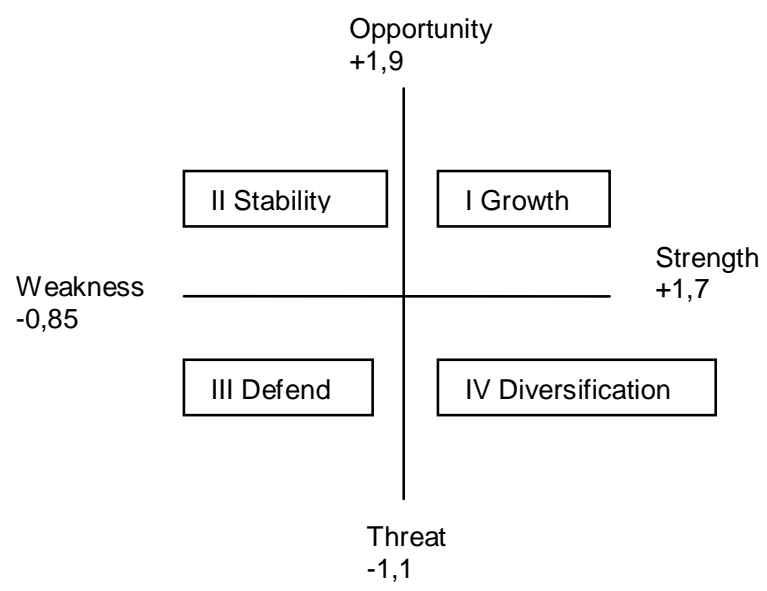

Fig 2. SWOT Cartesius

Base on the SWOT cartesius diagram, the woven SMEs belong to quadrant 1 , which means the development strategy for SMEs is SO strategy. It is the strategy where strength and opportunity are used to develop woven business. The strategy is known as growth strategy in which woven SMEs need to utilize all of the strength factors to seize and maintain opportunities. Growth quadrant is a beneficial strength as SMEs has the opportunity and strength to have all the available opportunities. Strategies need to be implemented are those supporting the rules and regulations for aggressive growth. From identification done in strength, it can be seen that woven SMEs have the strength in the availability of weavers, entrepreneurial totality, product diversification and easy access to raw materials. For weakness factors however are low quality in weavers, high woven products cost, small number of marketers and the ineffective usage of social medias. As for opportunity factors, there are interest in North Sumatra, woven as cultural legacy, an affiliation with Bank Indonesia (BI) and galleries ownership. Threat factors identified are the support given by the government is not yet optimum, complicated bureaucracy, consumers' mindset towards woven products and no community for woven SMEs.

Referring to SO strategy, then the entrepreneurial totality observed is the passion, motivation, entrepreneurial orientation, ability to face risks, vision, leadership skill, and determination in entrepreneurship. Those are the characteristics which must be found in an entrepreneur. Product diversification that has been done has to be developed by following the changing lifestyle and trends as woven products are not only worn in traditional event or celebrations but also can be worn as fashion attributes also they can be for home decor purpose. The easy access to raw materials and 
availability of weavers can be the strength factors to improve woven products and the affiliation with Bank Indonesia which provides galleries for products showcase also adds the strength factors. Woven products serve as a cultural legacy product. It also acts as the attractiveness point in North Sumatra where woven products such as Ulos is famous of. These are therefore a great opportunity to keep developing woven products.

Besides SWOT diagram, total values of each factors can also be served in SWOT matrix formula that will draw out score of each combination strategy shown in the table below.

TABLE 3. Quantitative Strategy Combination of Woven SMEs

\begin{tabular}{|c|c|c|}
\hline $\begin{array}{ll}\text { EFAS } & \text { IFAS } \\
\end{array}$ & STRENGTH = S & WEAKNESS $=\mathrm{W}$ \\
\hline $\begin{array}{l}\text { OPPORTUNITIES } \\
=\mathrm{O}\end{array}$ & $\begin{array}{l}\text { SO strategy } \\
1,7+1,9 \\
=3,6\end{array}$ & $\begin{array}{c}\text { WO strategy } \\
0,85+1,9 \\
=2,75\end{array}$ \\
\hline THREAT $=\mathrm{T}$ & $\begin{array}{l}\text { ST strategy } \\
\begin{array}{c}1,7+1,1 \\
=2,8\end{array}\end{array}$ & $\begin{array}{l}\text { WT strategy } \\
\begin{array}{c}0,85+1,1 \\
=1,95\end{array}\end{array}$ \\
\hline
\end{tabular}

Strategy combination on Table 4.3 shows that SMEs are better off with SO strategy because it has the highest score at 3.6. Then, it is followed by ST strategy with the score of 2.8 , WO strategy 2.75 and last is WT strategy with 1.95 as the score. SO strategy uses strength and opportunity to develop woven SMEs. Therefore the implementation for the development strategies for woven SMEs in Medan are as follow:

1. Woven SMEs need to keep improving woven quality by utilising the strength of weavers who are available and accessible so they have good skills in weaving. This can be done through trainings and workshops to enhance their skills.

2. Woven SMEs need to keep improving woven quality by utilising the strength of weavers who are available and accessible so they have good skills in weaving. This can be done through trainings and workshops to enhance their skills.

\section{RESULT AND DISCUSSION}

\section{A. Results}

Woven SMEs are in quadrant 1 with growth strategy. Therefore the implementation for its development strategies for woven SMEs in Medan can be done as follows:

1. Woven SMEs need to increase woven quality through weavers by providing trainings and workshops to improve their weaving skills.

2. With entrepreneurial totality in woven SMEs owners, it is expected to develop creative ideas in order to keep developing the existing galleries in order to increase its popularity and existence in Medan. Creativity is very important in entrepreneurship in order to make the galleries and SMEs to be appealing.

\section{B. Discussion}

The recommendations in this research are:

1. SMEs owners should have entrepreneurial totality to keep developing the business.

2. The government should provide serious and right supports to develop and promote woven products.

\section{REFERENCES}

Ramadini and Nasution, "The sustainability of competitive advantage strategy for small medium enterprise for textile sector to face the ASEAN Economic Community (AEC)," The 10th International Conference on Business and Management Research (ICBMR) 2016, Faculty of Economics and Business University of Indonesia, 2016, p 49.

[2] Saiman, Leonardus, "Kewirausahaan, teori, praktek dan kasus-kasus," Salemba Empat, Jakarta, 2009.

[3] Hindasah, Lela, "Strategi survival dan faktor-faktor penentu survival industri kecil (studi empiris industri gerabah, Kasongan, Bantul, Yogyakarta), Prosiding Seminar Internasional dan Call for Papers "Towards Excellent Small Business". Yogyakarta, 2011.

[4] Demirbag,M,Tatoglu,E,Tekinsus,M and Zaim,S, "An analysis of the relationship between TQM implementation and organizational performance:evidence from Turkish SMEs. Journal of Manufacturing Technology Management, 2006.

[5] Brock, W and Evans,D, "The economics of small business: their roles and regulations in US economy.” Holmes \& Meier Publishers. Teaneck.NJ, 1986.

[6] Acs, Z and Audretsch,D, "The economics of small firms: a european challenge.” Kluwer Academic Publishers.Norwall.MA, 1990.

[7] Megasari, Kartika Ayu, "Identifikasi kesiapan daya saing industri kecil menengah (IKM) alas kaki di kota Mojokerto 
menghadapi pasar bebas. Fakultas Ekonomi dan Bisnis Universitas Brawijaya, 2014.

[8] Tambunan T, "Beberapa isu penting", Jakarta: Salemba Empat, 2002, p.49.
[9] Sugiyono, "Metode penelitan kuantitatif kualitatif dan R\&D," Bandung: Alfabeta, 2013, p.85. 